\title{
UNEMPLOYMENT AND THE EFFECT OF HYSTERESIS - THE CASE OF THE REPUBLIC OF MACEDONIA
}

\author{
НЕЗАПОСЛЕНОСТ И ХИСТЕРЕЗИС ЕФЕКАТ - СЛУЧАЈ РЕПУБЛИКЕ \\ МАКЕДОНИЈЕ
}

\section{Predrag Trpeski ${ }^{1}$}

Ss. Cyril and Methodius University in Skopje, Faculty of Economics - Skopje, R. Macedonia

Igor Ivanovski

Ss. Cyril and Methodius University in Skopje, Faculty of Economics - Skopje, R. Macedonia

\begin{abstract}
The Republic of Macedonia is faced with high and persistent unemployment which remains over $30 \%$ during the period of transition.Taking this into consideration, the task of this paper is to offer an explanation for the high and persistent rate of unemployment in Macedonia in the period of transition. Explanation for long-term and persistent unemployment in Macedonia is based on the concept of the hysteresis theories, which is an approach primarily used on behalf of the new Keynesian economy. Having in mind the different theories about the concept of hysteresis, the paper offers a comprehensive analysis about the applicability of this concept at the labor market in Macedonia.

The central point of this paper is the question "Whether and to which extent the shortterm shocks on the side of the aggregate demand in Macedonian economy, that led to increase in the factual unemployment, could be treated as being one of the sources for permanent rise of unemployment?" Or in other words, "Is it possible to recognize Hysteresis at the labor market in the Republic of Macedonia?"

Results of the paper will serve to academic, scientific, professional and political public in explaining the problem of unemployment in the country.Results and conclusions will also serve to policy makers, primarily to the Government, Ministry of Finance and the Central Bank, to understand the effect of neglecting the short run in the economy and to create adequate policyfor management of aggregate demand.

Keywords: unemployment, hysteresis, aggregate demand, economic policies.
\end{abstract}

\section{INTRODUCTION}

Hysteresis, is not originally economic term, but is borrowed from physics. In physics hysteresis has multiple meanings. Magnetic hysteresis means dependence on the induction of the state of magnetism in the previous period, while the elastic hysteresis is a phenomenon in which the elastic bodies after the termination of the force that had changed their form are not returned in their original form immediately, but after a while.

${ }^{1}$ predrag@eccf.ukim.edu.mk

Vol. 16, бpoj 4/2014, cmp. 79-94 
In fact, the elastic hysteresis indicates the time required elastic bodies to return (full or nearly) to their original state.

A number of representatives of the new Keynesian economics believe in the existence of a phenomenon called Hysteresis. It is assumed that the term Hysteresis for the first time in the economy is used by Professor Edmund Phelps, Nobel Prize Winner in Economics for 2006 and means the dependence of the equilibrium natural rate of unemployment from the previous, historical equilibrium rates of unemployment, i.e. dependence of the macroeconomic equilibrium on the long run from the occasional (short term, incidental) shocks on the aggregate demand side.

Basically there are two explanations for the causes for the rise in the unemployment rate in the eighties of the last century, which caused a rise in the NAIRU in the developed economies, mainly in European countries. Then in the economic ether circled two explanations for the increasing the NAIRU. According to the first explanation, the underlying cause for the higher rates of unemployment and the increase of the NAIRU are institutions (unions, minimum wage law, active and passive labor market policies, fiscal policy, etc.), that decrease the flexibility of wages on the labor market, disable its fast cleaning and create involuntary unemployment. However, in some countries this is not confirmed. In the 80 -ies of the last century the power of the trade unions in the UK was reduced, but it does cause a reduction in the unemployment rate.

This led the new Keynesians in economic ether to place second explanation, which starts from the fact that the actual rate and the natural rate of unemployment (NAIRU) are influenced by short-term fluctuations in the aggregate demand. The models that explain that the natural rate of unemployment is determined by the rate of unemployment in the previous period are known as Hysteresis theories.

Because our goal is to analyze the effect of hysteresis in Macedonia, in the paper, despite the theoretical foundations of this concept are covered and its effects on the Macedonian unemployment and whole economy during transition period. The paper is structured in seven parts together with introduction and conclusion. In the second part of the paper are described the effects of stabilization policies in Macedonia at the beginning of transition and their impact on aggregate demand. Particular attention is paid to the 1992-1995 period, known as the period of disinflation, when inflation from $1925.6 \%$ in 1992 was reduced to $9 \%$ in 1995. But the cost of disinflation was rapid growth in unemployment. Unemployment in the same period grew from $27.8 \%$ in 1992 to $37.7 \%$ in 1995 and remained above $30 \%$ throughout the whole transition period. The third, fourth and fifth part of the paper refers to the concept of 
hysteresis, various hysteresis theories and the four basic channels (The insider-outsider distinction, Discouraged workers, Search and mismatch and The capital stock) through which the effect of hysteresis are manifested in the economy. In the sixth part is explained the manifestation of the hysteresis effect in Macedonia during the transition period. In fact this section explains that short-term shocks on the aggregate demand side caused long-term consequences for the Macedonian economy, which are manifested by extremely high and persistent unemployment in the transition period. The seventh part includes the conclusions of the research.

\section{ECONOMIC POLICIES AND SHOCKS ON THE AGGREGATE DEMAND SIDE IN MACEDONIA}

One of the main priorities of Macedonia, in transition from a centrally-planned to a market system, was the establishment control over inflation. Inflation reached its peak of $2,736 \%$ in December 1989, or average inflation of $1,246 \%$ for the same year. However, the establishment control over inflation was more difficult than in developed market economies, because parallel to this problem had to perform the liberalization of the prices, liberalization of foreign trade and the establishment of market institutions.

Taking this in to consideration, Macedonia was forced to bring its monetary independence in classic hyperinflationary chaos, when in April 1992 monthly inflation rate was over 80\%, with a tendency to further increase (Petkovski 1994, p. 25). Macedonia was caught in a spiral of high inflation.

Once the foundations of a market economy were established, further control of inflation could not be established through administrative measures, as it was in the previous system, but through appropriate policies of aggregate demand management. "These policies incorporate three elements: a) establishing control over the money supply and credit expansion in favor of enterprises; b) applying appropriate income policies that should ensure the level of salaries to be consistent with the objectives of the stabilization program and c) control over fiscal deficits and their considerable reduction."(Bishev 1994, 145-146).

The biggest shock on aggregate demand occurred in the period from independence until 1995, known as a period of disinflation. Taking into consideration that the main priority was to establish control over inflation, economic policy makers were fully focused on aggregate demand and through distinctively restrictive economic policies, mainly

Vol. 16, бpoj 4/2014, стр. 79-94 
restrictive monetary and fiscal policy and policy for controlling wages and prices, in 1995 inflation was reduced to a single digit. Policies on the aggregate demand side, mainly restrictive monetary and fiscal policy, successfully achieved their goal of reducing the rate of inflation.

Table 1.: Macroeconomic indicators 1992-1995 Index, base 1992

\begin{tabular}{|c|c|c|c|c|c|c|c|}
\hline $\begin{array}{c}\text { Yea } \\
\mathrm{r}\end{array}$ & \multicolumn{2}{|c|}{ Real GDP $^{1}$} & \multicolumn{2}{|c|}{ Unemployment } & \multicolumn{2}{c|}{ Employment } & Inflation \\
\hline & Denars $^{2}$ & $\begin{array}{c}\text { Inde } \\
\mathrm{x}\end{array}$ & Total & $\begin{array}{c}\text { Inde } \\
\mathrm{x}\end{array}$ & Total & $\begin{array}{c}\text { Inde } \\
\mathrm{x}\end{array}$ & $\%$ \\
\hline $\begin{array}{c}199 \\
2\end{array}$ & $\begin{array}{c}418,000,00 \\
0\end{array}$ & $\begin{array}{c}100 . \\
0\end{array}$ & $\begin{array}{c}172,08 \\
9\end{array}$ & $\begin{array}{c}100 . \\
0\end{array}$ & $\begin{array}{c}446,11 \\
7\end{array}$ & $\begin{array}{c}100 . \\
0\end{array}$ & 1925.2 \\
\hline $\begin{array}{c}199 \\
3\end{array}$ & $\begin{array}{c}392,000,00 \\
0\end{array}$ & 93.8 & $\begin{array}{c}174,84 \\
8\end{array}$ & $\begin{array}{c}101 . \\
6\end{array}$ & $\begin{array}{c}421,02 \\
8\end{array}$ & 94.4 & 229.6 \\
\hline $\begin{array}{c}199 \\
4\end{array}$ & $\begin{array}{c}382,000,00 \\
0\end{array}$ & 91.4 & $\begin{array}{c}185,90 \\
6\end{array}$ & $\begin{array}{c}108 . \\
0\end{array}$ & $\begin{array}{c}395,68 \\
6\end{array}$ & 88.7 & 55.4 \\
\hline 199 & $376,000,00$ & & 216,22 & 125. & 356,61 & & \\
5 & 0 & 90.0 & 2 & 6 & 6 & 79.9 & 9.2 \\
\hline
\end{tabular}

Source: Authors calculation according to the National Bank of the Republic of Macedonia, Annual reports 1992, 1993, 1994, 1995 and 1996.

${ }^{1}$ Real GDP is calculated at constant prices from 1990.

${ }^{2}$ Denar is the national currency of the Republic of Macedonia.

Obviously in the period 1992-1995 Macedonia made enormous disinflation efforts, which predictably resulted in a high social cost, drastically reducing GDP growth and increasing the unemployment rate.

As you can see from the Table 1, over the period of disinflation, when restrictive monetary and fiscal policies were implemented, as well as some other measures (wage and price control) to limit aggregate demand, there is a permanent reduction in employment and gross domestic product, followed by a permanent increase in unemployment. These conclusions would be logical and expected as a consequence of implementation of discretionary macroeconomic policies for reducing inflation focused on the aggregate demand side.

In the period after 1995, although the main goal, the reduction of inflation to single digit, was reached, it does not change the course of macroeconomic policies. Aggregate demand management remained a major focus of macroeconomics policies and the main goal was keeping inflation on low and stable level. Because price stability was reached, that is key for long term investment decisions, conditions for "awakening" of aggregate supply was created (Bishev 2004, p. 69). However, the rates of economic growth in Macedonia in the period after 1995 remained low. 
Under strong influence by the events of the period of disinflation, economic policymakers conceptualized restrictive monetary and fiscal policy in the period after 1996. This commitment in running key macroeconomic policies are maintained for a long time and lasted until 2008, when Macedonia was affected by the great world financial and economic crisis. Small exception was in 2001 when due to internal conflictthere appeareda redesign of the fiscal and monetary policy. As a result of increased spending from the budget for the security of the state, although Government introduced additional duty - war tax on each transaction, the budget ended with a high fiscal deficit of $5.7 \%$ of GDP. The Central Bank responded with a more restrictive monetary policy, which was an important precondition for the maintenance of price stability, while not in derogation from the strategy of targeting the exchange rate.

Redesign of monetary and fiscal policy in Macedonia happened in 2008 when the first symptoms of great global financial and economic crisis were felt. In 2008, private consumption, investment and public consumption had real growth on annual level of $7.8 \%, 16.5 \%$ and $9.6 \%$, respectively. The growth of private consumption and enhanced investment activity in 2008 caused a strong trend of growth of aggregate demand. This was substantiated by reducing interest rates and facilitated access to bank loans.

The pressures on aggregate demand, which led to raising the general level of prices, and inflation which reached higher rates, required redesign of macroeconomic policies (see Mankiw 1994, p. 335, 336 and Stiglitz 1993, p. 1069). In Macedonia, under conditions of running the strategy of fixed exchange rate and strengthened budgetary spending, the new situation required changes in monetary policy and aimed at stabilizing the inflation and inflationary expectations and maintenance the exchange rate of the Macedonian denar. For this purpose the National Bank of the Republic of Macedonia, in the first half of 2008, undertook two measures: First, in Februarythe National Bank had changed policy from "tender with interest rates" towards auctioning of treasury bills on a principle "tender with amount" and Second, on 12.06.2008 the Central Bank adopted Decision for compulsory deposit that banks and savings banks are obliged to pay to the Central Bank if their credit growth of population exceedsthe projected rates of growth (National Bank of the Republic of Macedonia 2008, p. 80). These measures on the aggregate demand side, followed by stabilization of the price of food and oil, in the second half of 2008, contributed for stabilization of inflation and inflationary expectations. 


\section{HYSTERESIS CONCEPT}

In Hysteresis models the natural rate of unemployment (NAIRU) is increased if the current rate of unemployment in the previous period was greater than the natural rate of unemployment (NAIRU) in the period. This can be explained by following equation: (Snowdon and Vane 2005, p. 405)

$$
\mathrm{UNt}=\mathrm{UNt}-1+\mathrm{a}(\mathrm{Ut}-1-\mathrm{UNt}-1)+\mathrm{bt}
$$

In the equation UNt is a natural rate of unemployment in period $t$, $\mathrm{UNt}-1$ is the natural rate of unemployment in the previous period, Ut-1 is the current unemployment rate in the previous period and bt are other impacts on the natural rate of unemployment, such as social transfers to the unemployed etc. If we assume that $b t=0$, then the equation will have the following form: (Snowdon and Vane 2005, p. 405)

$$
\mathrm{UNt} \text { - UNt-1 = a (Ut-1 - UNt-1) }
$$

The equation leads to following conclusion: UNt $>$ UNt-1 when Ut-1 > UNt-1. Actually, when the current unemployment rate in period t-1 is higher than the natural rate of unemployment in that period it causes a raise in the natural unemployment rate in period $t$. High current unemployment rate, as a magnet, pulls also the natural unemployment rate up.

\section{HYSTERESIS THEORIES}

Hysteresis theories can be divided into two groups (Blanchard and Summers 1987, p. 288):

- Membership theories and

- Duration theories.

Membership theories are based on the relations between insiders and outsiders and explain the thesis that labor market wages are determined more by workers employed in companies (insiders) than by those who are not employed in companies (outsiders). These theories in economics can be found as theories of insiders and outsiders and emphasize the power of insiders, who affect the amount of wages, reduce their flexibility and enable the labor market balance.

The second group of theories is theories of duration based on the relations between short-term and long-term unemployment and elaborate the thesis that long-term unemployment exerts a slight pressure on wage setting in the labor market. These theories emphasize that when Ut $>\mathrm{UNt}$ the problem of structural unemployment deteriorates because the unemployed suffer depreciation of their human capital, which leads to further reduction the possibility of employment (beyond in Snowdon, 
Vane and Wynarczyk 1994, p. 324).The high unemployment rate further generates an increase in long-term unemployment, which as mentioned, has little influence on the wage setting in the labor market, and it causes a rise in the NAIRU.

\section{CHANNELS THROUGH WHICH HYSTERESIS MANIFESTS}

There are four channels that Hysteresis may feed through:

$>$ The insider-outsider distinction;

$>$ Discouraged workers;

$>$ Search and mismatch and

The capital stock (Begg, Fischer and Dornbusch 2000, p. 480).

\section{The insider-outsiderdistinction}

Outsiders are persons who are not employed. Only insiders, employed persons, participate in wage setting. Firstly, when the economy is in equilibrium, with higher level of resources exploitation, there are many insiders who work and create conditions in which real wages are low enough to keep their own jobs. In terms of the recession some insiders get fired and become outsiders. Moreover, after some time the economy will enter a phase of expansion and the labor demand will return to the initial level, but now the number of insiders will be lower than at the beginning. Insiders, even less numerous, use their position and are demanding higher salaries for themselves, and do not encourage new hiring in their companies. The economy remains caught in equilibrium trap, with high real wages and low employment, rather than a balance of low wages and high employment. Since then, only with the measures on the supply side, the economy can gradually get out of this balance of low employment.

\section{Discouraged workers}

The starting point again is the assumption that the economy is in equilibrium with a high level of resource utilization and skilled and energetic workforce. If recession came along, this would surely lead to increased unemployment. If the recession prolongs, the long-term unemployment is inherent and in such conditions unemployed usually stop seeking for job. When labor demand is increased and returned to the initial level, labor supply is permanently reduced. Even in this case, only

Vol. 16, бpoj 4/2014, стр. 79-94 
long-term measures, dealing with the supply side, are adequate to restore the work culture and give desired results.

\section{Search and mismatch}

In terms of low unemployment, companies advertise jobs and seek for workers; meanwhile the workers are trying hard to find a good job. If the recession happened, companies would advertise fewer jobs and workers would realize that looking for job is just a waste of time. When demand increases again, firms and workers are already accustomed to not-looking for workers/work, which means no new working places will be opened. The economy will be in equilibrium but at higher real wages and higher unemployment.

\section{The capital stock}

Initially, starting from the assumption that the economy is in equilibrium at high resources utilization, there is a large amount of capital and labor productivity is high. During the recession, companies save and give up on investing. Their capital is significantly reduced. When demand for goods increases, firms have permanently lower capital, and therefore, the demand for labor, which depends on the marginal labor income, will not return to the original level. Economy resumes to equilibrium but at a lower employment rate than at the beginning.

In this way the new Keynesians explain the effect of hysteresis in the labor market. Thus, from the above presentations following can be concluded: when the economy is caught in equilibrium trap at high real wages and low employment, the appropriate solution are long-term measures focused on the aggregate supply.

\section{HYSTERESIS IN MACEDONIA}

The crucial point is the question whether and to what extent the short-term aggregate demand shocks in Macedonian economy, which led to an increase in the actual unemployment, can be treated as one of the roots of permanent increase in unemployment? Or in other words, whether the phenomenon of Hysteresis can be recognized in the labor market in Macedonia?

Looking backwards, from the period before Macedonian independence until today, it can be concluded that unemployment in Macedonia has trend of permanent growth. High unemployment had its roots even before the transition period. It is inherited from the period 
before the transition, since the unemployment rate during the independence was $22.6 \%$. Furthermore, during the transitional period, the unemployment rate increased continuously and reached its highest level of $37.3 \%$ in 2005 . Also, it should be considered the unemployment rate in Macedonia has a long-term character. Unemployment lasts longer than 4 years in 1997 was $15.7 \%$, which represents $43.6 \%$ of total unemployment, while in 2008, at the beginning of the world financial and economic crisis, the unemployment rate that lasted longer than 4 years rose to $228 \%$ and accounted $68 \%$ of total unemployment (Trpeski 2011, p. 263).

According to the previously mentioned, further attention should be paid to the applicability of the concept of Hysteresis in interpreting the unemployment in Macedonia. Turning back to the four channels through which Hysteresis manifests, it can be noted that all the channels to a greater or lesser extent manifest in Macedonia. However, it should be taken into account that these channels are mutually intertwined and therefore isolated effects of each of these cannot be seen individually.

The first channel, the insider-outsider distinction, is permanent in the transition period. Considering the fact that many of the workers have lost their jobs, they became outsiders. Workers who remained in private companies and public sector are insiders. At the beginning of the independence the unemployment rate was $22.6 \%$, but because of the negative trends in the economy, unemployment increased. The number of insiders drastically reduced and the number of outsiders increased. After 1995 year, when the economy started to achieve positive rates of economic growth and the demand for labor increased, outsiders were already outside firms. Insiders, though less numerous, were at an advantage for two reasons: First, part of the merits for companies' survival in crisis certainly had to be attributed to them (insiders) andSecond, the privatization process was underway, and managers in that period looked to please existing employees (insiders).

This allowed insiders to demand higher wages from their employers. Of course employment remained low, unemployment continued to rise.

Table 2 shows the first five years of independence and transition of the state, mentioned as a period of disinflation, in which, as we seen in part 2, are happened great shock on aggregate demand side with longterm consequences on the labour market in Macedonia. In table are presented unemployment and employment rates for 2000, 2005, 2010 and 2013 with aim to show that unemployment remained the level above $30 \%$ during whole period of transition. 
Table 2.: Employees (insiders) and unemployed (outsiders)

\begin{tabular}{|c|c|c|}
\hline Year & Employment rate & Unemployment rate \\
\hline 1991 & 30.3 & 26.0 \\
\hline 1992 & 28.5 & 27.8 \\
\hline 1993 & 26.6 & 29.3 \\
\hline 1994 & 27.1 & 32.0 \\
\hline 1995 & 24.0 & 37.7 \\
\hline 2000 & 35.8 & 32.2 \\
\hline 2005 & 33.9 & 37.3 \\
\hline 2010 & 38.7 & 32.0 \\
\hline 2013 & 40.6 & 29.0 \\
\hline
\end{tabular}

Source: State statistical office of RM, Statistical yearbooks 1991-1996, 2002, 2006, 2011, 2014 and National Bank of the Republic of Macedonia, Quarterly Bulletin II/2014

At the beginning of transition employment are decreased drastically and unemployment rose above 30\%. Employment rate from $30.3 \%$ in 1991 decreased to $24 \%$ in 1995 . At the same period, unemployment increased from $26 \%$ in 1991 to $37.7 \%$ in 1995 which created an army of unemployed persons (outsiders). Further, throughout the period of transition, unemployment remained over $30 \%$. From a total of 468,372 employees in 1991, till 1995 work lost 111,756 people and became outsiders. Those who kept the work, mostly in the companies that were in the process of privatization, in 1995 were only 356,616. They were insiders, with strong influence on managers of the firms, because they were shareholders.

Also, the channel discouraged workers has its effects on the labor market in Macedonia. As the crisis has lasted several years, some of the workers have already lost hope and de-motivated to work. Again, the labor demand shock caused long-term reduction in labor supply. Part of the workers gave up seeking for the job. When labor demand started to increase, a good portion of the workforce was already discouraged to seek for work. Many of persons who have registered as unemployed in Employment Service Agency of the Republic of Macedonia (ESARM) have done so, mainly to take advantage of the right to health care.

In table 3 are shown total number of unemployed and those unemployed persons who are registered in the ESARM with motive to use the right of health care insurance. Mostly, they are discouraged and did not search job. Such data EARM publish only for 2007, 2008 till may 2009. But it is enough to show that after more of 15 years transition, in Macedonia exist discouraged workers and their number is large. 
Unemployment and the effect of hysteresis - the case of the Republic of Macedonia

Table 3.: Registered unemployed persons and discouraged workers

\begin{tabular}{|l|c|c|}
\hline & Unemployed & Unemployed who are not seeking work \\
\hline 2007 December & 357,166 & 75,508 \\
\hline 2008 December & 343,363 & 71,589 \\
\hline 2009 May & 349,063 & 70,924 \\
\hline
\end{tabular}

Source: Employment Service Agency of the Republic of Macedonia, Review of registered unemployed in the period 1.1.2007 to 31.12.2007, 1.1.2008 to 31.12.2008 and 1.1.2009 to 31.05.2009).

As we can see from the table, from 375,166 unemployed persons at the end of 2007, 75,508 did not search work. They are registered in ESARM with aim to use health care insurance. This means that $21.2 \%$ of unemployed not looking for job, large number of them are discouraged workers, and one part works in a grey sector. Situation is almost the same and in 2008. Namely, in December 2008, 271,774 from a total of 343,363 registered unemployed, actively searching job. But, 71,589 persons or $20.8 \%$ are registered as unemployed but they did not looking for job.

Closely associated with this channel is search and mismatch channel. Since Macedonian enterprisesdidnotrequirenew workers for longer period of time unemployed peopleknew thatsearching for jobisa waste of time so theycreateda habit of notlookingforwork. Companiesinturncreateahabitnot to advertise jobs. When companies started to advertise jobs, unemployed people were already accustomed to not looking for a job. Certainly this condition is lately being exceeded through various trainings for the unemployed.

Table 4.: Long term unemployment

\begin{tabular}{|c|c|c|c|c|c|c|c|}
\hline \multirow[b]{2}{*}{ Year } & \multicolumn{3}{|c|}{ Unemployment \% } & \multirow[b]{2}{*}{ Year } & \multicolumn{3}{|c|}{ Unemployment \% } \\
\hline & Total & $\begin{array}{l}4 \text { years } \\
\text { and more }\end{array}$ & $\begin{array}{l}\text { Under } \\
4 \text { years }\end{array}$ & & Total & $\begin{array}{l}4 \text { years } \\
\text { and more }\end{array}$ & $\begin{array}{l}\text { Under } \\
4 \text { years }\end{array}$ \\
\hline 1997 & 36.0 & 15.7 & 20.3 & 2005 & 37.3 & 24.4 & 12.9 \\
\hline 1998 & 34.5 & 19.5 & 15.0 & 2006 & 36.0 & 23.9 & 12.1 \\
\hline 1999 & 32.4 & 19.2 & 13.2 & 2007 & 34.9 & 22.7 & 12.2 \\
\hline 2000 & 32.2 & 19.5 & 12.7 & 2008 & 33.9 & 22.8 & 11.1 \\
\hline 2001 & 30.5 & 19.8 & 10.7 & 2009 & 32.2 & 20.5 & 11.6 \\
\hline 2002 & 31.9 & 20.0 & 11.9 & 2010 & 32.0 & 20.2 & 11.8 \\
\hline 2003 & 36.7 & 23.3 & 13.4 & 2011 & 31.4 & 19.5 & 11.9 \\
\hline 2004 & 37.2 & 23.9 & 13.3 & 2012 & 31.0 & 18.9 & 12.1 \\
\hline
\end{tabular}

Source: State statistical office, Statistical yearbooks 1997-2013. 
As we can see from the Table 4, unemployment in Macedonia is structural, with long-term character. In the period 1997-2012 number of unemployed persons of 4 years and more is very large in comparison with total unemployment. In the same period average rate of unemployment is $33.8 \%$, but unemployment of 4 year and more is $20.9 \%$ of total unemployment. Given that this unemployment takes long period of time, we can conclude that long-term unemployed people are discouraged and they lost their habit for job searching.

According to one survey done in Macedonia in 2014, most of the new employees are from inactive population, while a small fraction of the employed persons are from the registered unemployed people in the ESARM (Trpeski 2014).

And fourth channel through which Hysteresis manifests, the capital stock, has its effects on the labor market in Macedonia. For a longer period, which include the beginning of the period after independence, the Macedonian economy drastically decreased investments in fixed assets.

Table 5.: Investments in fixed assets in Macedonia

\begin{tabular}{|c|c|c|c|c|}
\hline \multirow{2}{*}{ Year } & \multirow{2}{*}{$\begin{array}{l}\text { Investments in } \\
\text { fixed assets in } \\
\text { million denars }\end{array}$} & \multirow{2}{*}{ Employment } & \multicolumn{2}{|c|}{$\begin{array}{c}\text { Investment in fixed assets per } \\
\text { employee }^{1}\end{array}$} \\
\hline & & & Denars & $\begin{array}{c}\text { Index } \\
\text { base } 1992\end{array}$ \\
\hline 1992 & 30,219 & 446,117 & 67,738 & 100.0 \\
\hline 1993 & 27,824 & 421,028 & 66,086 & 97.6 \\
\hline 1994 & 25,435 & 395,686 & 64,281 & 94.9 \\
\hline 1995 & 28,027 & 356,616 & 78,592 & 116.0 \\
\hline 1996 & 29,854 & 537,591 & 55,533 & 82.0 \\
\hline 1997 & 28,570 & 512,301 & 55,768 & 82.3 \\
\hline 1998 & 27,833 & 539,762 & 51,565 & 76.1 \\
\hline 1999 & 27,430 & 545,222 & 50,310 & 74.3 \\
\hline 2000 & 26,560 & 549,846 & 48,304 & 71.3 \\
\hline 2001 & 24,276 & 599,308 & 40,506 & 59.8 \\
\hline 2002 & 28,548 & 561,341 & 50,857 & 75.1 \\
\hline 2003 & 28,862 & 545,108 & 52,948 & 78.2 \\
\hline 2004 & 32,008 & 522,995 & 61,202 & 90.4 \\
\hline 2005 & 30,280 & 545,253 & 55,534 & 82.0 \\
\hline 2006 & 33,792 & 570,404 & 59,243 & 87.5 \\
\hline 2007 & 38,219 & 590,234 & 64,753 & 95.6 \\
\hline 2008 & 40,283 & 609,015 & 66,145 & 97.6 \\
\hline 2009 & 38,551 & 629,901 & 61,202 & 90.4 \\
\hline 2010 & 37,510 & 637,855 & 58,807 & 86.8 \\
\hline 2011 & 38,710 & 645,085 & 60,008 & 88.6 \\
\hline
\end{tabular}


Graph 2.: Dinamic of investments in fixed assets per employee

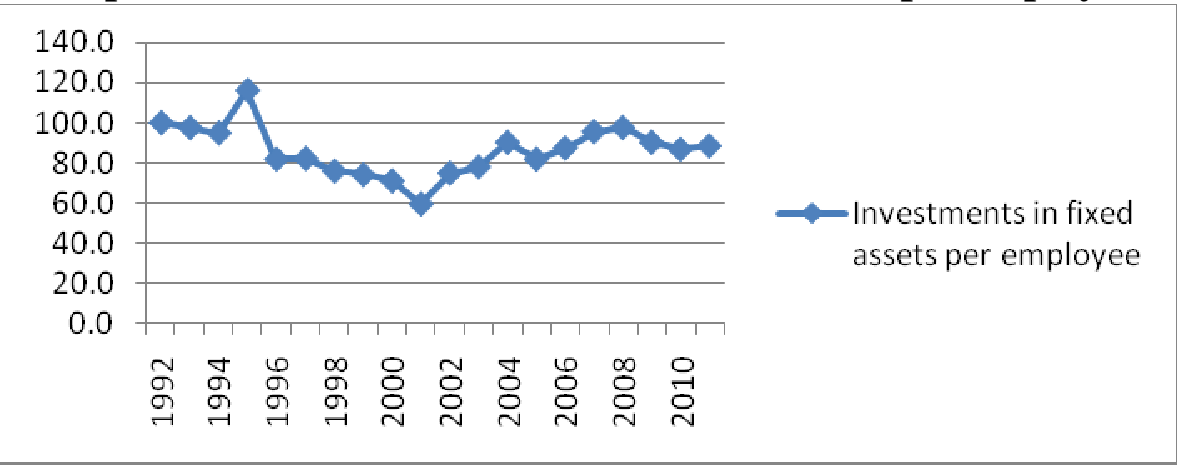

The low share of investments in GDP have conditioned the emergence of the phenomenon of disinvestment, condition when the depreciation of the fixed assets is greater than the investment that would allow their simple replacement (Kljusev 1998, p. 19-20, Kljusev 2002, p. 21-29). This decrease of investments reduced labor demand and labor demand curve has shifted to the left. In 1995, when the economy stabilized and in the next period began to realize positive economic growth rates, companies already had permanently lower capital. At a lower level of capital, the labour demand of Macedonian firms, which depends on the marginal revenue (productivity) of labor, never returned to previous level. This is how the new Keynesian economics would explain the effect of hysteresis in the labor market in Macedonia.

As can be seen from Table 5 and Chart 2 investments in fixed assets per employee in the transition period is not increased and they are below level from 1992. This significantly affected, in Macedonia, labour productivity, in the whole period of transition, to remain on a low level and it caused the demand for labour by Macedonian firms to remain low longer period. This confirmed that the aggregate demand shock in the period 1992-1995 (period of disinflation), cause long-term consequences on the labour market in the Republic of Macedonia.

It is obvious that the state of the labor market in Macedonia, as well as the growth and keeping unemployment high a longer period of time, can be explained by Hysteresis theories.

\section{CONCLUSION}

Hysteresis concept is applicable and relevant approach in explaining the unemployment in Macedonia. If the four channels, through which Hysteresis manifests (the insiders-outsiders distinction, 
discouraged workers, search and mismatch and the capital stock) are considered, it can be concluded that all these channels to a greater or lesser extent exist in Macedonia. The fact is that aggregate demand shocks, which led to an increase in the actual unemployment rate, are one of the sources of the permanent increase of unemployment in Macedonia. It can be concluded that aggregate demand management is highly important.

The aggregate demand management should eliminate short-term shocks, which have negative effects in the long run. From this point of view, the aggregate demand management should ensure Hysteresis effect does not happen. This makes sense if the economy is in equilibrium. When the economy is in equilibrium, the aggregate demand management is very important to prevent the effect of Hysteresis. But, once the effect of hysteresis already happens, as it was the case in Macedonia during the stabilization period (1992-1995), and the economy is in equilibrium at high real wages (compared to equilibrium) and low employment, then appropriate solution are long-term measures focused on the aggregate supply side. Greater focus on aggregate demand and neglect of aggregate supply is a feature of the economic policies in the Republic of Macedonia in the transition period. Aggregate supply was neglected due to the slow restructuring of the real sector and the slow implementation of other structural reforms. Considering the fact that in Macedonia aggregate supply is at low level and is a growing curve (a situation which is a starting point for Keynes, moderate Keynesians and new Keynesians), it was thought that through macroeconomic policies on the aggregate demand side, enhancing of the Macedonian economy could be ensured. But, there is an oversight made by Keynes and Neo-Keynesians (without new Keynesians) which is over-emphasis of aggregate demand.

\section{LITERATURE:}

1. Employment Service Agency of the Republic of Macedonia, Review of registered unemployed in the period 1.1.2008 to 31.12.2008, 2009, 2010, 2011 and 2012.

2. Begg, D., (1998), "Disinflation In Central and Eastern Europe: The experience to Date", BoCottarelly, C., and Szapary, G., Moderate Inflation - The Experience of Transition Economies, IMF and National Bank of Hungary.

3. Begg, D., Fischer, S. and Dornbusch, R. (2000), Economics, sixt edition, McGraw-Hill Publishing Company. 
4. Ball, L., and Mankiw, G., (2002), "The NAIRU in Theory and Practice", Journal of Economic Perspectives, Vol. 16, No. 4. (p. 115-136).

5. Bishev, G. (1994), "Stabilization efforts in transition countries", Economic transition, conditions, problems, perspectives, Macedonian Academy of Sciences and Arts, Skopje.

6. Bishev, G., (2004), "Policies for Managing Aggregate Demand", Open Challenges of the Macedonian Economy, Macedonian Academy of Sciences and Arts, Skopje.

7. Blanchard, O. and Summers, L. (1987), "Hysteresis and Unemployment" European Economic Reviw, Vol. 31, No. 1/2.

8. Blanchard, O. and Summers, L., (1987), "Husteresis and European Unemployment Problem", NBER Working Paper Series, No. 1950.

9. Blanchard, O., and Wolfers, J., (1999), "The role of Shocks and Institutions in the Rise of European Unemployment: the Agregate evidence", NBER Working Paper Series, No. 7282.

10. Dobbie, M., (2004), "Hysteresis and Insider-Outsider Theory: a Literature Review", Macquarie University, Department of Economic, Research Paper No. 0408.

11. Kljusev, N. and all, (2002), Economy of Macedonia in transition, Macedonian Academy of Sciences and Arts, Skopje.

12. Leon-Ledesma, M. and McAdam P., (2003), "Unemployment, Hysteresis and Transition", Working Paper Series, Working Paper No. 234, European Central Bank.

13. Lindbeck, A., and Snower, D., (2001), "Insiders versus Outsiders", Journal of Economic Perspectives, Volume 15, Number 1.

14. Lindbeck, A., and Snower, D., (2002), "Insider-Outsider Theory: A Survey", Discussion Paper Series, Institute for the Study of Labor, DP No. 534.

15. Mankiw, G (1994 b), "Interview with Gregory Mankiw", in Snowdon, B., Vane, H. and Wynarczyk, P. (1994), AModernGuidetoMacroeconomics, Edward Elgar Publishing Company.

16. National Bank of the Republic of Macedonia, Annual Reports 1992, 1993, 1994, 1995, 1996, 2008.

17. National Bank of the Republic of Macedonia, Quarterly Bulletin II/2014 
18. Petkovski, M., (1994), "Strategies of Transition: central issues", Economic transition, conditions, problems, perspectives, Macedonian Academy of Sciences and Arts, Skopje.

19. Phelps, E. (1972), Inflation Policy and Unemployment Theory: The Cost-Benefit Approach to Monetary Planning, New York, W. W. Norton.

Рад је примљен: 06.06.2014.

Рад је прихваћен за штампање: 21.10.2014. 